\title{
JOB SATISFACTION AND RELATIONS WITH THE LEADER ON AN EXAMPLE OF A DOMESTIC COMPANY
}

\author{
UDC: 005.322:316.46 \\ Original Scientific Paper

\begin{abstract}
Nikola PETROVIĆ ${ }^{1}$, Edit TEREK ${ }^{2}$, Dragana SAJFERT ${ }^{3}$, Zoran JOVANOVIĆ ${ }^{3}$, Tamara PETKOVIĆ ${ }^{4}$
\end{abstract} \\ ${ }^{1}$ Republic of Serbia \\ E-mail: petrovic.n26@gmail.com \\ ${ }^{2}$ University of Novi Sad, Technical faculty “Mihajlo Pupin” Zrenjanin, 23000 Zrenjanin, Đure Đakovića bb, \\ Republic of Serbia \\ ${ }^{2}$ College Dositej, 11000 Belgrade, Bulevar vojvode Pitnika 7, Republic of Serbia \\ ${ }^{3}$ Higher agricultural school of vocational studies, Šabac, Republic of Serbia
}

Paper received: 06.11.2019.; Paper accepted: 25.11.2019.

\begin{abstract}
This paper presents a survey of job satisfaction and relation with the leader, ie the measurement of the quality of the relation between employees with superiors. Job satisfaction is an important factor in the quality of business. This research is important for the consideration of employee satisfaction and their relationship with the superiors in order to increase the business performance of the company. The aim of the research is to determine the state of the observed organizational performance, job satisfaction and the relationship with the supervisor in the observed company. The results will be presented through practical suggestions on what kind of relationship the superiors should develop with their employees, in order to achieve better performance of the company. Questionnaires were filled out by respondents, that is, employees in the observed company. Answers from a total of $N=33$ employees were collected. The analyzed results of job satisfaction and the relationship with the superior shows that employees in the observed company are generally satisfied.
\end{abstract}

Keywords: Job satisfaction; Leadership; Employees; Organization.

\section{INTRODUCTION}

Job satisfaction is related to the general attitude of individuals to their job (Vukonjanski and Nikolić 2013). Every organization is made up of people, or employees in it. That is why it is important to understand the human behavior, its sources, shape and consequences essential to the leadership of the team of people in order to achieve together the desired goals of the organization. Employee job satisfaction is one of the most frequently explored topics in the field of human behavior in an organization. The collective actually has an identity within the boundaries of an organization it makes, but it is also connected with the company outside the organization. Such a collective can in many respects be distinguished from other social communities eg family (Bratton, 2016). Job satisfaction is defined as a pleasant feeling arising from the notion that one's work fulfills or allows the fulfillment of important business values of that person. This definition shows three essential aspects of job satisfaction. First, job satisfaction is a function of value (defined as something that a person consciously or unconsciously wants to achieve). Second, employees have different views on what skills are important (which is critical in determining the nature and level of their job satisfaction). The third aspect is one's perception of the situation with respect to the values it appreciates (Radić, 2015). Job dissatisfaction can significantly influence behaviour of employees which results in absence from work, complaints and termination of employment (Vukonjanski and Nikolić 2014).

In theoretical approaches, the scientists tried to answer questions about the factors of job 
satisfaction, so there are three different approaches (Radić, 2015):

- Disposition - job satisfaction is a stable positive or negative attitude towards the job,

- It is related to the social sphere and relates to the information that other people communicate in relation to the business,

- A cognitive-information model that is based on information that an individual accumulates in relation to the job he performs and the environment in which he / she works.

Leadership can be said to be a complex process in an organization that is realized by the interaction of leaders and followers who should support and modify the attitudes of the follower. Leadership deals with changes, starting from generating a vision of the future to gathering people around the idea given in the vision and motivating them to overcome all obstacles encountered on the way to achieving the goal generated in the vision (Sajfert et al., 2012). Leaders must be motivators of both the company's and team members' advancement and development. Leaders apply modern trends in learning and understanding new knowledge in organizations in order to achieve greater success, survive and be more competitive on the market. A leader must have high emotional intelligence to align their personal goals with the organizational goals in order to perform the company's tasks (Sajfert et al., 2011). Leadership implies an approach to people management in an organization based on one person's influence on another person independently of the formal right to realize that influence (Petrović et al., 2018). Without influence, leadership does not exist (Northouse, 2016).

Leadership plays an important role for the organization and its employees, as it represents the ability to influence the group in order to fulfill the vision of leaders. That is why leaders today need more than ever, capable and very elastic leaders of the new age. Modern business conditions create huge and unknown changes which every organization faces on a daily basis. Global market brings great challenges and constant changes in business environment. An organization's survival on the competitive market will depend on its ability to adapt to changes (Petrović, Tatomirov, \& Joksimović, 2017). Traditional strategic approach implies a hypothesis according to which managers can predict future market trends precisely enough to choose a clear strategic direction just by using the set of analytical tools. On the other hand, when market flows are really turbulent and tend to become chaotic, this traditional approach is marginal and even dangerous for the future of business organization (Đorđević et al., 2016).

\section{LITERATURE REVIEW}

Job satisfaction is widely recognized as a critical component of institutional success (Bilyalov, 2018). One of the ways in which organizations can achieve their goals is when their staff is satisfied and engaged at workplace, and consequently job satisfaction relates to many sides of employee engagement. Even though, there is no universal definition of job satisfaction that covers all dimensions of the construct, most definitions emphasize, job satisfaction as the degree to which people enjoy doing their job (Tepayakul and Rinthaisong, 2018). Job satisfaction is one's personal attitude towards one's job and has been described as the set of positive desires or positive feelings that people have toward their jobs and employment by their organization, (Hamidi et al., 2014). The components which should be considered as important determinants of job satisfaction can be grouped together under the heading of intrinsic and extrinsic job satisfaction (Tepayakul and Rinthaisong, 2018).

Basically job satisfaction is individual. Each individual has a different level of job satisfaction. Job satisfaction is an important factor in the organization because it can affect the productivity of employees because employees who have high job satisfaction will see their work as fun, different of employee who has a low job satisfaction. Employees who work in forced situations have a poor performance compared to those who work with high spirits (Agus and Alamsyah, 2018).

In this contemporary world, business organizations are faced with complex challenges (Agarwal and Sajid, 2017). The factors that can affect job satisfaction are self work, supervision, salary, promotion opportunities, and relationship with coworkers. There are consequences when an employee likes or dislikes a job. One of them is if the employee shows disloyal behavior he/she will be out of work and do not care of anything (Agus and Alamsyah, 2018).

Affective dimension of job satisfaction is defined as satisfying or positive emotional state which results from estimation of a job or work 
experience. Although job satisfaction is more an attitude than behaviour many managers expect results because satisfied workers will come to work more regularly and stay in the company for longer (Vukonjanski and Nikolić, 2013). Job satisfaction represents the extent to which needs, desires and expectations that one brings to the job are met. On the same line, stated that job satisfaction is the employees' evaluative judgment on the amount of affective and cognitive pleasure he or she derives from his or her job (Agarwal and Sajid, 2017). It correlates significantly with such important organizational outcomes as productivity, organizational socialization, commitment, absenteeism, turnover, and mental health (Bilyalov, 2018). Job satisfaction is 'the extent to which people like (satisfaction) or dislike (dissatisfaction) their job. There are various organizational factors like pay, rewards, superior subordinate relationships, fringe benefits, human resource policies, promotion opportunities etc. that determines employees' job satisfaction (Agarwal and Sajid, 2017). When the leadership style of a supervisor satisfies employees' needs, that supervisor's effect is maximized. The implication of this is that a supervisor's effectiveness depends on what employees want (Shu, 2015).

Today's employees are working in turbulent, complex business environments that are characterized by globalization and rapid technological advances (Ho and Nesbit. 2014). The success of organization depends upon the involvement, efforts, and commitment of their labor or workforce. The main factor for organizational effectiveness is manager's leadership style. In present time organizations are more concerned about developing, understanding and modifying their leadership style in line with firm's strategy, structure and system. Leadership style has deep relevance and influence on the human resources of a firm in terms of attracting people to achieve the goals of organizations, (Haleem et al., 2018). The success of modern organizations is reflected in the ability to recognize changes, early diagnosis and assessment of results. It is also important to inform employees about the successful implementation of the change, the benefits of which have been acquired, thus putting to know how the changes are significant and how they could strengthen their significance (Stanisavljević et al., 2015).

Leadership style plays a vital role in influencing employee's job satisfaction. Job satisfaction is the behavior and attitude of an employee towards his job and organization that is highly influenced by the work process and environment. Likewise, both negative and positive feelings of an employee towards his/her job determine employee's job satisfaction that is a key factor in increased productivity and organizational success (Haleem et al., 2018).

Leadership is a process involving the interaction of a set of guidelines, the engagement of employees, as well as those that follow, and agree with their motivations and inspirations. Leadership exists in all parts of the organization and therefore represents the most important element. The leader must be sure that the strategy, values and goals in the entire organization are set up in the right way (Mihailović and Tanasković, 2017). The leader is a person who has the skills, behavior and power to influence a group of people in order to achieve his vision (Petrović, Bakator, Terek, Ivetić, \& Joksimović, 2017). Business excellence represents the main goal of modern business and it results in the leadership competitive position (Đođrević et al., 2016). Business environment has been changing permanently. The changes are under the strong influence of technological progress and the process of global market unification. Changes are permanent and business organizations have to make models of behaviour in relation to the observed and anticipated changes (Đorđević et al., 2016). Management system implies an impact - it affects the manager followers (Popović et al., 2010).

An interesting issue is whether the leadership performance at different levels of management and presence of specific experiences and knowledge influence the perception and evaluation of the importance of certain characteristics that the leader should possess (Sajfert et al., 2016). Strong and competent leadership improves the knowledge and skills of employees in the organization (Petrović et al., 2018). Companies that didn't manage to develop an adequate level of leadership can face several issues, including lower process flexibility; higher risks of failure; and ineffective resource allocation (Bakator et al., 2018).

Leaders usually focus on the future, they are those who inspire their members in the organization and create the image of organizations and companies (Petrović, Sajfert, \& Ivin, 2017). Organizations need a leader figure who has the ability to influence the group to achieve a defined vision and 
purpose. The activities done by leaders in organizations are called leadership. In the theory of leadership it is explained that the person who will be chosen to be a leader is who has better knowledge of his followers, has the nature of a leader (fair, confident, creative, energetic, communicative), is able to socialize, is charismatic and certainly have talent. Leadership is considered as a factor that has a major influence on the performance of organizations, managers and employees (Agus and Alamsyah, 2018).

The differences between the leaders of private and public companies reflect the impact of the privatization on the management (Sajfert et al., 2016). In modern business, organizations want their teams to be built within the organizational structure of the company, so the teams are built by several leaders, as one leader in the organization is not enough. The key to a modern organization is not its own capabilities, but the knowledge and capabilities of the leaders within the company. Leadership in the domestic economy is still tied to ownership, that is, the power deriving from ownership. Also, on the domestic market, the perception of leadership as inherent characteristic prevails (Petrović et al., 2018). There are, of course, many definitions but it can be said that organizational culture assumes the achieved knowledge and experience which an individual uses in the development process of his/her organizational behavior (Vukonjanski et al., 2015).

Indicators of leadership functions include the following (Agus and Alamsyah, 2018):

- Leaders are able to move and motivate subordinates to carry out orders, leaders conduct consultations with subordinates who have the information required in determining decisions,

- Leaders try to enable subordinates to participate in making decisions and in implementing them,

- Leaders delegate authority in decision-making based on trust,

- Leaders who share the same principles, perceptions and aspirations with subordinates,

- The leader is able to organize the activities of its members in a direction and in effective coordination,

- Leaders conduct guidance, direction, coordination, and supervision to subordinates.

Successful leadership will lead to increased subordinate work, because conductive leadership can provide great motivation and enthusiasm within the organization (Agus and Alamsyah, 2018). The essence of the struggle for competitiveness lies in the acceptance of change (Ćoćkalo et al., 2015). Also, leadership has a relationship with many elements significant for communication and organizational learning, such as: organizational structure, culture, climate, change, and others (Mitić et al., 2017).

\section{RESEARCH METHODOLOGY}

Job satisfaction questionnaire was used. This questionnaire has 12 questions on which the respondents answered. The respondents gave values ranging from 1 to 6 (Likert's scale in six points).

1. I feel that I am adequately rewarded for the work I do.

2. I have enough opportunities to improve my work.

3. My first superior is competent for the job he is doing.

4. I am satisfied with the benefits I receive.

5. When I do a good job, I get the recognition that belongs to me.

6. I love the people I work with.

7. My work has a pronounced meaning and significance.

8. The bonuses are frequent and large.

9. Those who do their job well have a good chance of being promoted.

10. I feel that the work I do is appreciated.

11. I like doing jobs in my workplace.

12. My first superior shows a significant interest for the feelings of employees.

In order to measure the relationship with the leader, the Questionnaire for the measurement of the quality of employee relations with the superior was used. This questionnaire has 5 questions to which respondents gave values. Each question was rated by respondents ranging from 1 to 5 .

1. I have respect for the director as a person.

2. The director is the person that people would like to have as a friend.

3. It's fun to work with the director.

4. The director defends my actions in front of other superiors, even if he does not know exactly what the issue is.

5. The director would defend me if I were "attacked" by others.

The research was carried out in the company Jadran d.o.o. Belgrade on a small sample of 
employees who are employed in the financial, commercial sector, sector for legal, personnel and general affairs and heads of operational units in the technical sector. The survey does not include the operative workers because they have no contact with the company leader. Employees, who make up the sample, filled in questionnaires. $\mathrm{N}=33$ questionnaires were collected from the same number of respondents. Given that there are 40 employees, the sample covered a significant percentage of employees (82.5\%). Out of 33 respondents, there were 15 men and 18 women in the sample, 16 younger and 17 older respondents, 13 employees who completed high school and 20 employees who completed faculties.
Descriptive statistics were used that is represented through a diagram. The collected data were processed using descriptive statistical method followed by the comparison of data and parameters. The processed data is displayed graphically. The questionnaire used in the survey was attached as Appendix 1.

\section{RESULTS AND DISCUSSION}

On the basis of the obtained results, the diagram shows the mean value of the job satisfaction assessment and the quality of the employee's relationship with the superior, obtained through a questionnaire filled by the employees of the aforementioned company.

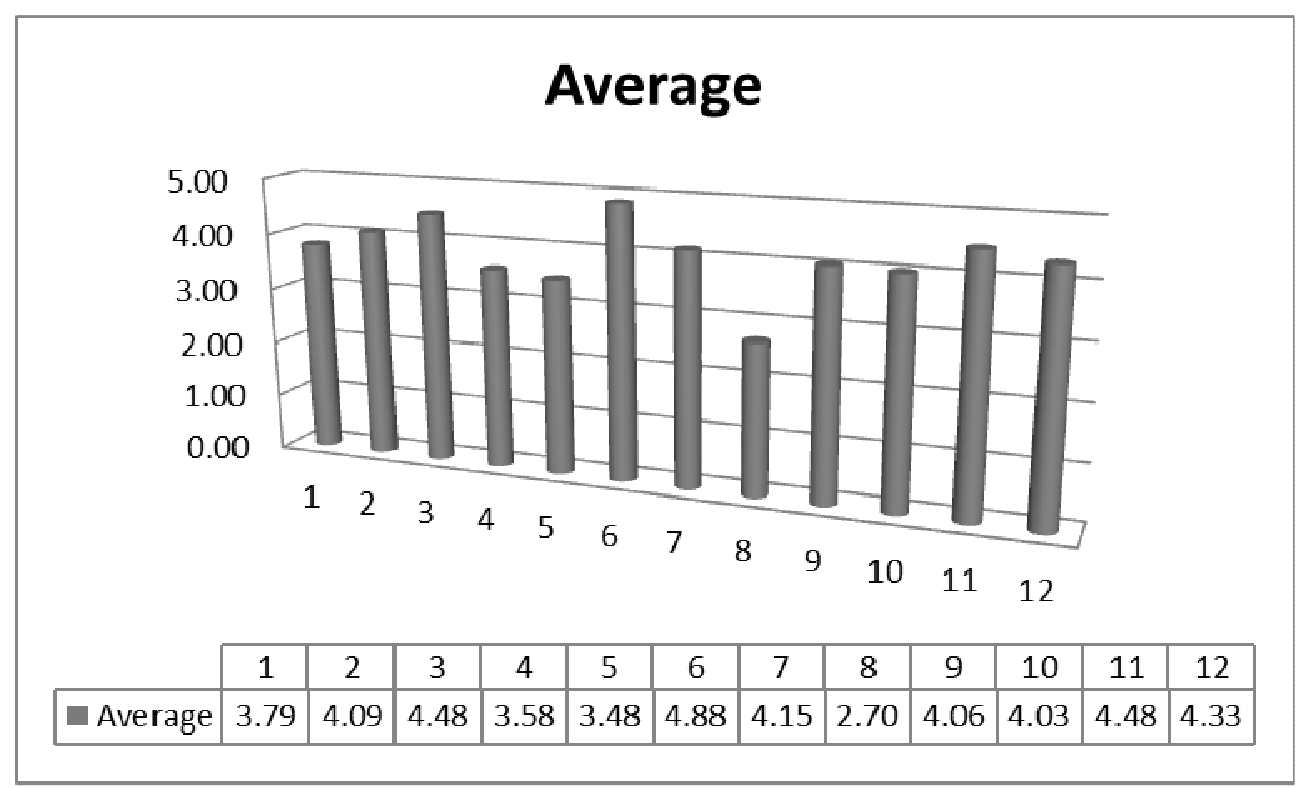

Figure 1: The obtained average job satisfaction level

Based on the results from Figure 1. it can be seen that the average grade of job satisfaction is 4.01 for this questionnaire. This shows that employees of the company Jadran d.o.o. Belgrade are pleased with their work. The highest average grade for employees has the question number 7. "I love the people I work with" for this questionnaire. Employees are obviously satisfied with the people they work with in their organization. This is very important for the company and the whole organization. It can be said on the basis of the obtained results that the other questions received average grades by the employees. For this questionnaire, the average rated was the issue under number 3. "My first superior is competent for the job he is doing" and question 11. "I like doing my job at my workplace ". It can be said that the employees are satisfied with the superiors and the work they do. For this questionnaire, the lowest grade was given to the question under number 8 . "The bonuses are frequent and large." In the current transitional conditions, in the Republic of Serbia that last for more than a decade, such results are mostly expected and comprehensible in full. 


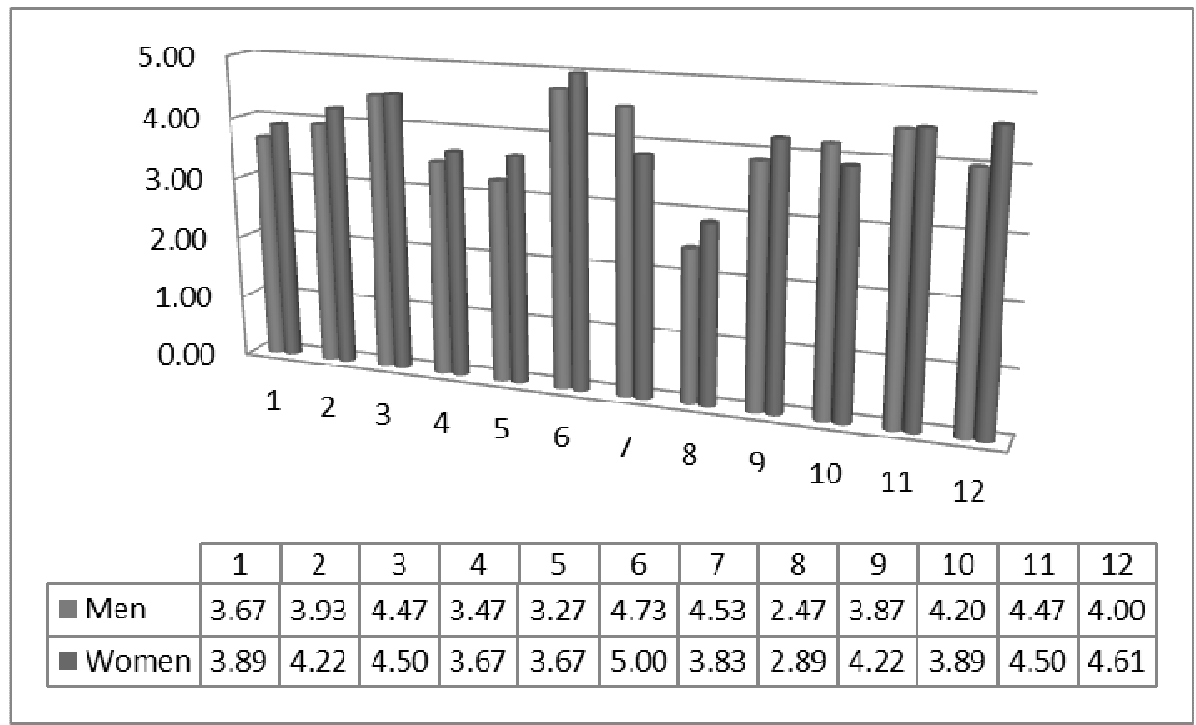

Figure 2: Average job satisfaction values by gender

Based on the results from Figure 2, the average job satisfaction values by gender are represented. We can see that women are more satisfied with their jobs than men. The highest average grade of women rated the question under number 7. "I love the people I work with" and My first superiors show a significant interest in the feelings of employees for this questionnaire. The lowest grade men gave the issue under number 5. "When I do a good job I get the recognition that belongs to me" and question 10. "The bonuses are frequent and large" for this questionnaire. For this reason, women are more satisfyed with theor job than men.

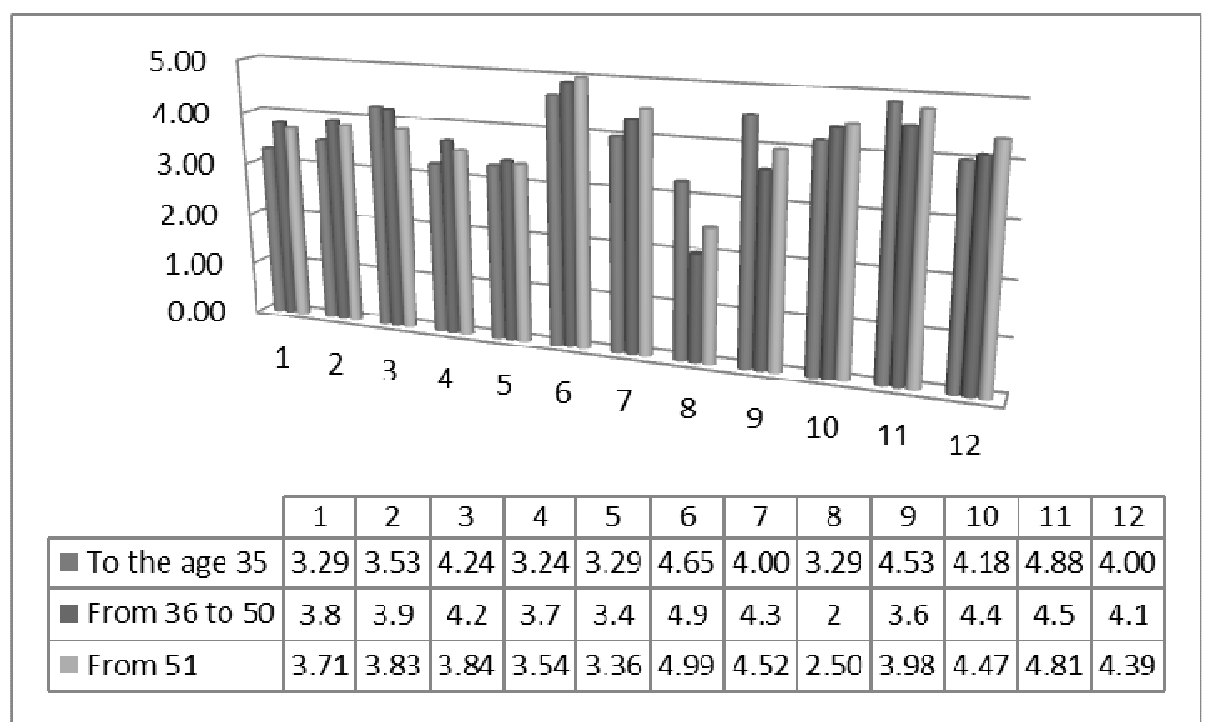

Figure 3: Average job satisfaction values by age of respondents

Based on the results from Figure 3, which presents the average assessments of respondents categorized by age group to younger, middle aged and older, we can see that older respondents are more satisfied with their job than younger and middle aged respondents. Younger employees have higher expectations of work, while employees of middle age are satisfied with their work in dealing with older respondents, their satisfaction with business can be overwritten by their tendency and length of stay in the mentioned company, because they appreciate greater privileges are satisfied with the situation as it is without the desire for some further changes. The highest average assessment of whether middle-aged employees and older employees rated the issue under number 7. "I love the people I work with" for this questionnaire. While the younger colleagues gave the lowest score to the issue under number 10. "Those who do their job well have a good chance of being 
promoted," for this questionnaire. Older work than younger and middle-aged employees. respondents are obviously more satisfied with the

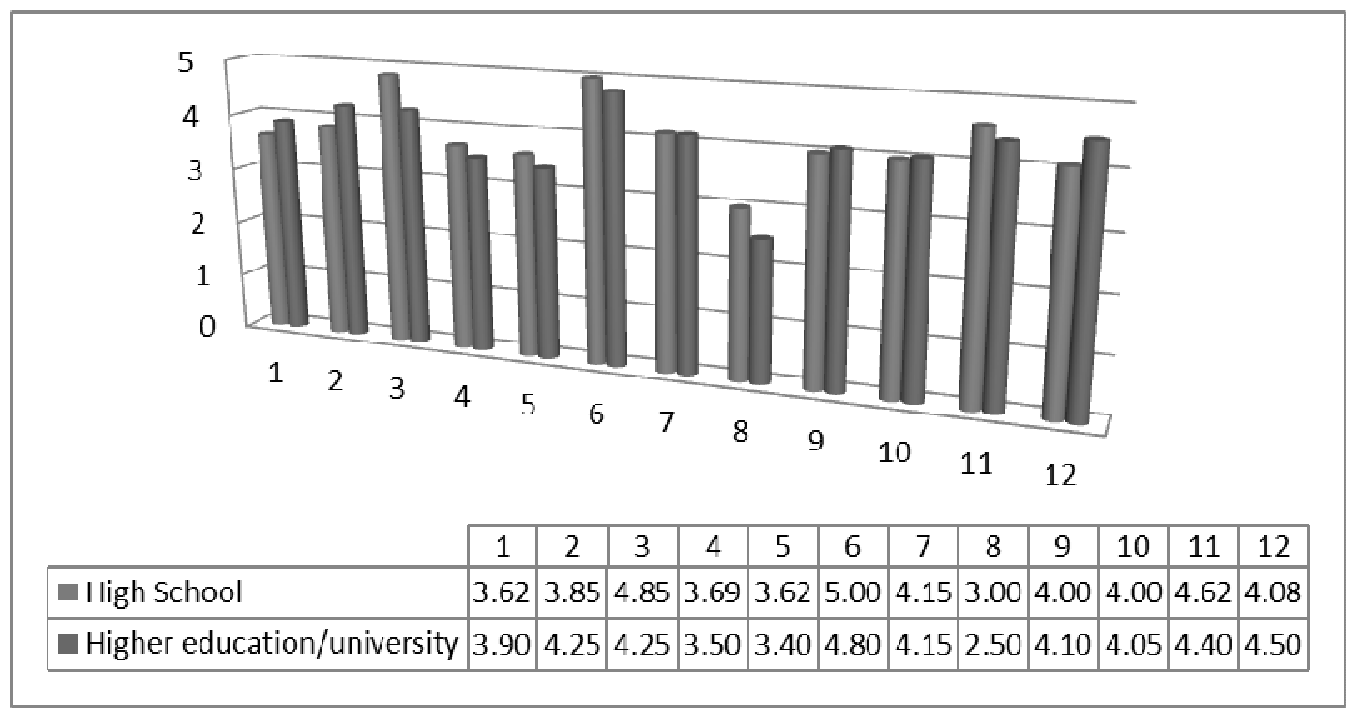

Figure 4: Average job satisfaction values by education

Based on the results from Figure 4, the average values for education level are presented. It can be seen that the ones who finished secondary school rated the highest grades to the question 7. "I love the people I work with" and 3. "My first superiors is competent for the job he is doing." Also, we can say that respondents with completed secondary school are somewhat more satisfied than respondents with completed faculties. The lowest value gain the questions: 10 . "The bonuses are frequent and large". I do not have to work hard in my workplace, so we can conclude that the respondents of this group consider that they are doing a lot of jobs but are not adequately rewarded for this.

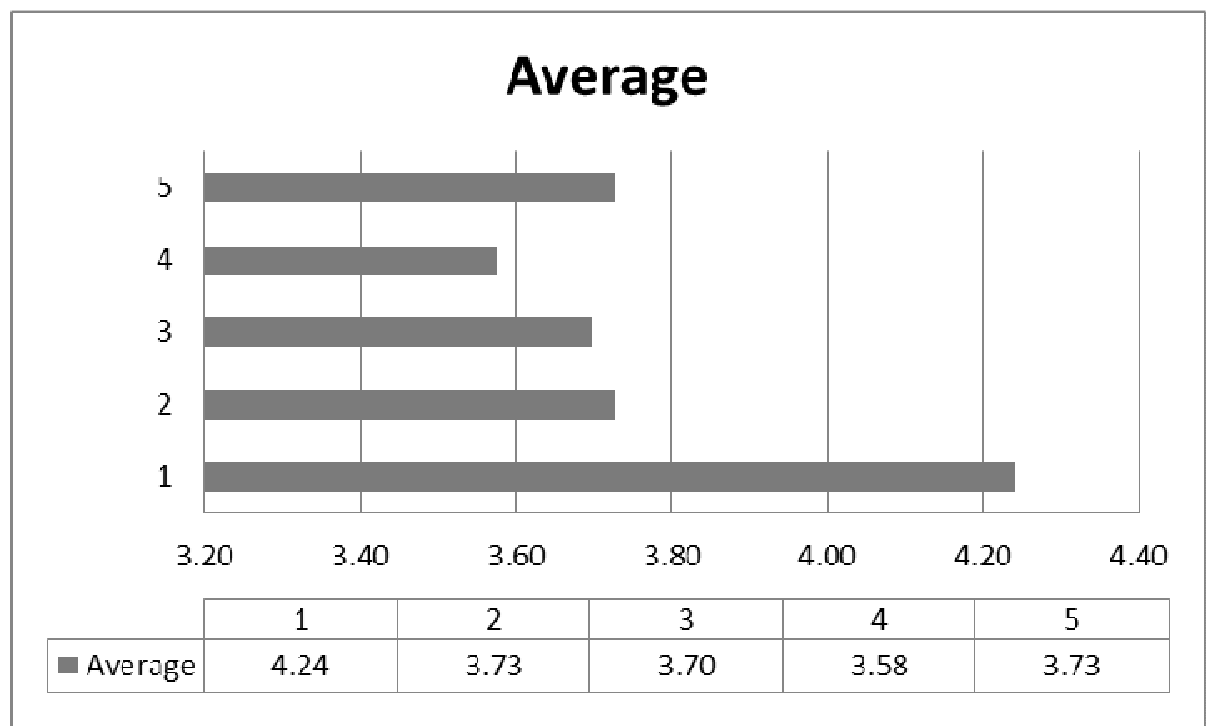

Figure 5: The obtained mean value of the quality of the employee's relationship with the leader

Based on the results in Figure 5. It is seen that average values for the quality of relationships with employees with superiors are more than average (3.79, for this questionnaire). This shows that employees of the company Jadran d.o.o. Belgrade are satisfied with the quality of the employee's relationship with the superior. The highest average grade of the employees rated the issue under number 1. "I have respect for the director as a person" for this questionnaire. It can be concluded that employees have a high opinion of their superiors. The lowest grade the employees gave 
the question under number 4. "The director defends my actions before other superiors, even if he does not know exactly what the problem is" for this questionnaire. It can be concluded in which segment the employees are not satisfied with their superior.

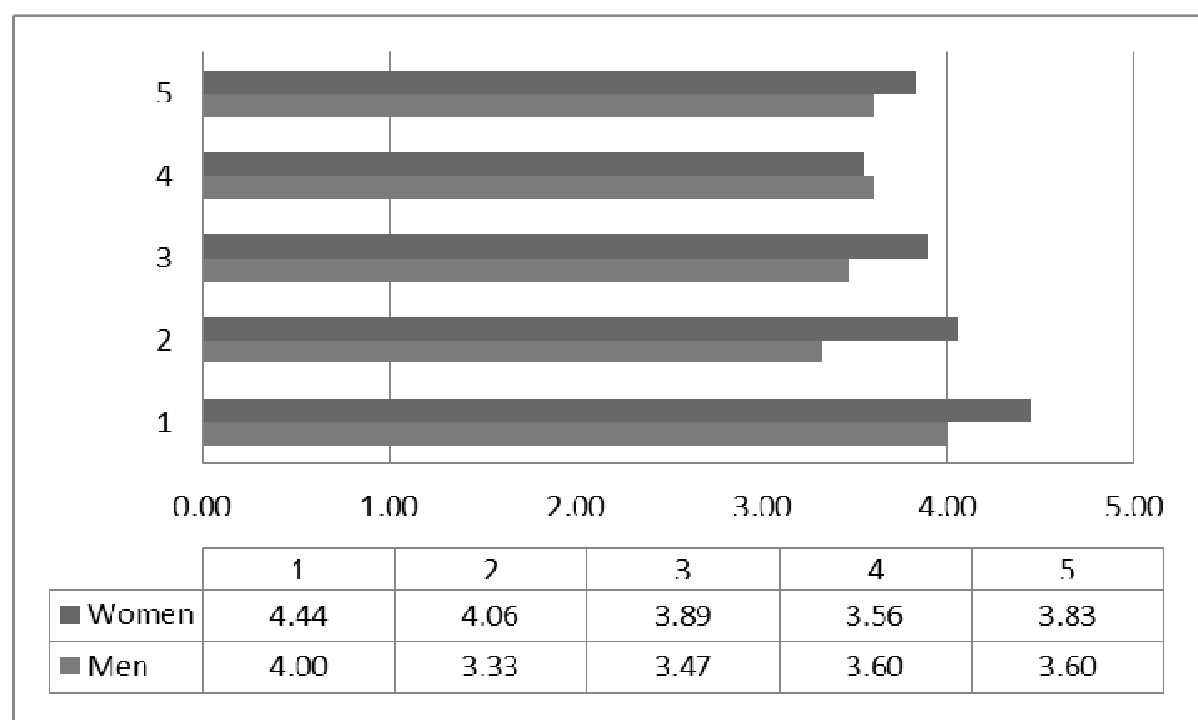

Figure 6: The obtained mean value of the quality of the employee relationship with the leader by gender

Based on the results from Figure 6, the results of the average assessment of the respondents according to the gender of employees in the company are presented. Women and men assessed their position with the superiors for this part of the questionnaire. The highest average grade was just given by women for the issue under number 1 . "I have respect for the director as a person" for this questionnaire. It can be said that women are more satisfied with their relationship with superiors than men. The lowest grade men rated the issue under number 2. "The director is the person that people would like to have as a friend," for this questionnaire. It can be concluded in which segment men are not satisfied with their superior.

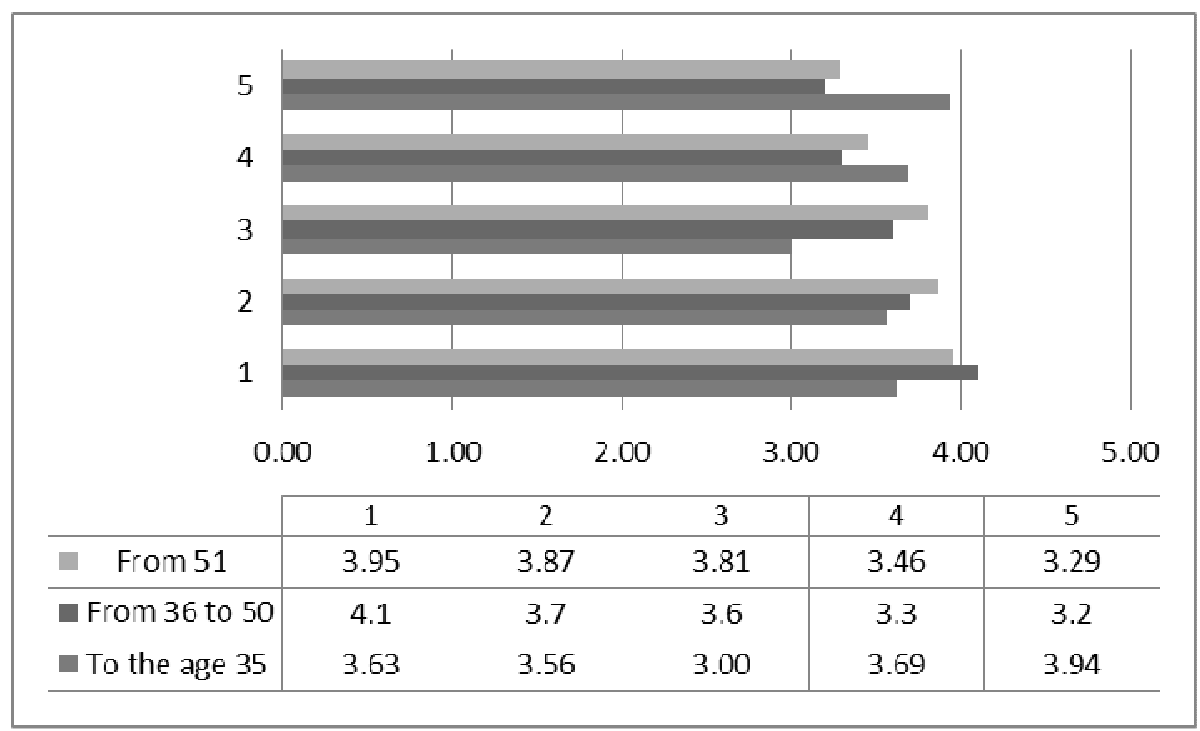

Figure 7: The obtained mean value of the quality of the employee relationship with the leader by age

Based on the results in Figure 7, the results of the mean assessment of the respondents by age, presented in three categories younger, middle aged and older, are presented. The highest average grade was given to respondents of the middle age group for question number 1 . "I have respect for the director as a person" for this questionnaire. It can be said that middle-aged employees are satisfied 
with their superiors. The lowest grade was given by the younger and older respondents with question number 3. "It's fun to work with the director" and the question 5. "The director would defend me if I was / was" attacked "by others", for this questionnaire.

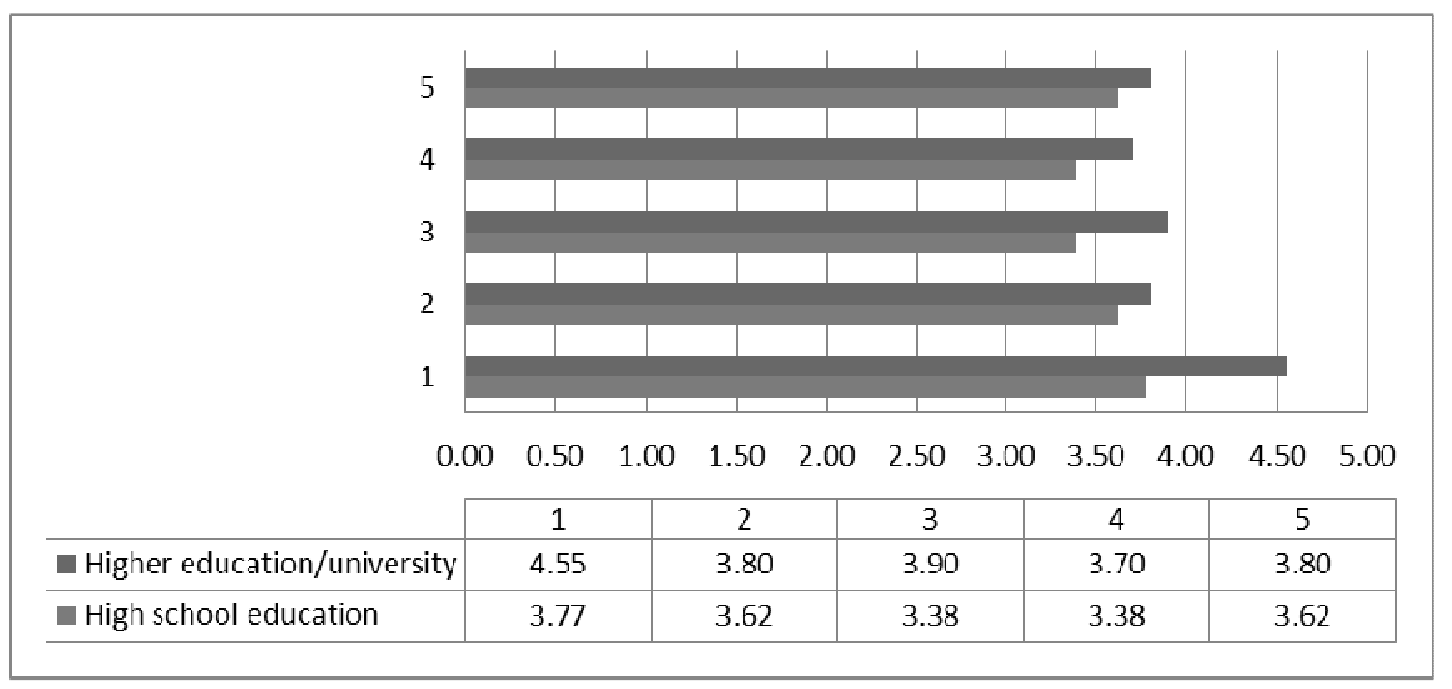

Figure 8: The obtained mean value of the quality of the employee relationship with the leader by education

Based on the results from Figure 8, on the average values of the respondents according to the education are presented. They are divided into two categories: secondary school, faculty. The highest average grade was given by respondents with faculty for question number under number 1 . "I have respect for the director as a person" for this questionnaire. It can be said that employees with a college or university are more satisfied with their superiors. The lowest grade was given by the secondary school level respondents 3 . It is fun to work with the director and 4 . "The director defends my actions before other superiors, even if he does not know exactly what the problem is" for this questionnaire. It can be concluded in which segment employees with secondary education are not satisfied with their relationship with their superiors.

\section{CONCLUSION}

When we look at the results of the survey, we can conclude that the majority of employees are dissatisfied with the reward system in the company, and that in relation to the answer to the question number 10. "Bonuses are frequent and large", it can be concluded that most employees expect financial reward for the work done, but the company does not give it or it is inadequate. However, according to the results, most employees are satisfied with the work they perform, as well as communication they have with each other as well as with their superiors.

The satisfaction of employees in the company can only be seen by the right-minded people at the head of the company who will be able to recognize the skills and knowledge of employees. Companies must send their employees to additional training to improve themselves in order to be able to follow new business conditions. A relatively small number of companies are trying to enable employees to improve their knowledge.

Such and similar research can significantly help and improve the business results of the company and increase the additional level of employee satisfaction. Therefore, such research should be carried out often in the company Jadran d.o.o. Belgrade. The conducted research relates only to the mentioned company and these results can be used only for the observed company. If other companies want to examine their employees and their satisfaction with their job and relationships with their superiors, it is recommended to the top management to conduct research and check the status of organizational behavior in their company.

According to the results of the research, in the observed company it can be concluded that job satisfaction and the relationship with the superior is at a satisfactory level. Also, these surveys point 
to a good relationship between employees and superiors, where misunderstanding and conflict are minimized, resulting in greater continuity and productivity in work, and hence the success of the company is guaranteed. It is well known that satisfaction with employee engagement promotes a better attitude towards work and with superiors, and from all this, employee loyalty, which is a significant factor in the quality of business. According to the data, it can be concluded based on the assessment of the results of job satisfaction that it is higher than the average and that the employees in this company are generally satisfied.

\section{REFERENCE}

Agarwal, P., \& Sajid, S. M. (2017). A Study of Job Satisfaction, Organizational Commitment and Turnover Intention among Public and Private Sector Employees. Journal of Management Research (09725814), 17(3), 123-136.

Agus, S., \& Alamsyah, L. S. (2018). The effect of leadership on organizational citizenship behavior through work climate and job satisfaction. Russian Jouranl of Agricultural and Socio-Economic Scinces, 76(4), 24-32.

Bakator, M., Borić, S., \& Petrović, N. (2018). Differences and similarites between Total Quality Management, ISO 9001, Lean production, and Six Sigma. International Journal "Advanced Quality", 46(1), 17-20.

Bilyalov, D. (2018). Organizational socialization and job satisfaction of faculty at Nazarbayev University in Kazakhstan. European Education, 50(3), 229-248.

Bratton, J. (2016). Introduction to work and organizational behaviour (3rd ed.). London: Palgrave.

Ćoćkalo, D., Đorđević, D., Bešić, C., \& Bogetić, S. (2015). Undergraduate business students' attitudes towards CSR and competitiveness of Serbian economy. Journal of engineering management and competitiveness (JEMC), 5(1), 12-20.

Đorđević, D., Ćoćkalo, D., \& Bogetić, S. (2016). The analysis of marketing concept implementation in domestic enterprises. Journal of engineering management and competitiveness (JEMC), 6(2), 120-128.

Haleem, F., Jehangir, M., \& Khalil-Ur-Rahman, M. (2018, May). Job satisfaction from leadership perspective. In Proceedings of the International Conference on Business Excellence (Vol. 12, No. 1, pp. 363-373). Sciendo.

Hamidi, N., Saberi, H., \& Safari, M. (2014). The effect of implementation of talent management on job satisfaction governmental organizations (Case Study: Ministry of Roads and Urban). Journal of Novel Applied Sciences, 3(1), 100-113.

Ho, J., \& Nesbit, P. L. (2014). Self-leadership in a Chinese context: Work outcomes and the moderating role of job autonomy. Group \& Organization Management, 39(4), 389-415.

Mihailović, L. B., \& Tanasković, A. M. (2017). Modern approach to quality management: The principles of total quality management. Tehnika, 72(5), 748-753.

Mitić, S., Nikolić, M., Jankov, J., Vukonjanski, J., \& Terek, E. (2017). The impact of information technologies on communication satisfaction and organizational learning in companies in Serbia. Computers in Human Behavior, 76, 87-101.

Northouse, P. G. (2016). Leadership: Theory and practice (7th ed.). Sage publications.

Petrović, N., Bakator, M., Terek, E., Ivetić, N., \& Joksimović, D. (2017). Managing organization by kaizen method. In D. Cockalo (Ed.), VII International Conference Industrial Engineering and Environmental Protection (IIZS 2017) (pp. 360363). Zrenjanin, Serbia.

Petrović, N., Ivin, D., Sajfert, D., Mjedenjak, M., \& Premčevski, V. (2018). The role of leadership in managing organizational changes. In D. Cockalo (Ed.), VIII International Symposium Engineering Management and Competitiveness (pp. 163-167). Zrenjanin, Serbia.

Petrović, N., Sajfert, D., \& Ivin, D. (2017). The impact of intellectual capital and leadership on the business performance of companies. Journal of Engineering Management and Competitiveness (JEMC), 7(2), 109-117.

Petrović, N., Tatomirov, N., \& Joksimović, D. (2017). Leadership as a prerequisite improving the quality of domestic enterprises. In D. Cockalo (Ed.), VII International Symposium Engineering Management and Competitiveness (pp. 145-149). Zrenjanin, Serbia.

Popović, B., Sajfert, D., \& Cvijanović, S. (2010). Istraživanje sistema menadžmenta. Industrija, 38(2), 81-90.

Radić, N. (2015). Uticaj motivacije zaposlenih na performanse organizacije. In Synthesis 2015International Scientific Conference of IT and Business-Related Research (pp. 353-358). Singidunum University.

Sajfert, D., Nikolić, M., Ćoćkalo, D., Đorđević, D., \& Lazić, J. (2016). The leadership and ethical leadership in the Serbian metal industry. Industrija, 44(1), 27-44.

Sajfert, Z., Adžić, S., \& Cvijanović, J. (2012). Korporativno liderstvo. Zrenjanin: Technical faculty "Mihajlo Pupin".

Sajfert, Z., Stanković, M., \& Istrat, V. (2011). Istraživanje uticaja emocionalne inteligencije lidera na produktivnost srpskih kompanija. Industrija, 39(2), 169-183.

Shu, C.-Y. (2015). The impact of intrinsic motivation on the effectiveness of leadership style towards on work engagement. Contemporary Management Research, 11(4), 327-350).

Stanisavljev, S., Klarin, M., Ćoćkalo, D., Đorđević, D., \& Sajfert, Z. (2015). Successful change 
management. In V. Spasojević-Brkić, M. Misita \& D. D. Milanović (Eds.), 6th International

Symposium on Industrial Engineering - SIE 2015 (pp. 121-123). Belgrade, Serbia: Faculty of Mechanical Engineering, Belgrade

Tepayakul, R., \& Rinthaisong, I. (2018). Job Satisfaction and Employee Engagement among Human Resources Staff of Thai Private Higher Education Institutions. The Journal of Behavioral Science, 13(2), 68-81.

Vukonjanski, J., \& Nikolić, M. (2013). Organizational culture and job satisfaction: The effects of company's ownership structure. Journal of engineering management and competitiveness (JEMC), 3(2), 41-49.

Vukonjanski, J., \& Nikolić, M. (2014). Moderating effect of national origin on relationship of organizational culture and job satisfaction. Journal of Engineering Management and Competitiveness (JEMC), 4(1), 3-12.

Vukonjanski, J., Nikolić, M., Terek, E., Ivin, D., \& Gligorović, B. (2015). The influence of LMX dimensions on certain dimensions of organizational culture in Serbian companies. Journal of engineering management and competitiveness (JEMC), 5(2), 61-67.

\section{ZADOVOLJSTVO POSLOM I ODNOS SA LIDEROM NA PRIMERU DOMAĆEG PREDUZEĆA}

U ovom radu predstavljeno je istraživanje zadovoljstva poslom i merenje kvaliteta odnosa zaposlenih sa nadređenim. Zadovoljstvo poslom predstavlja značajan faktor kvaliteta poslovanja. Ovo istraživanje je značajno zbog sagledavanja zadovoljstva poslom zaposlenih i njihov odnos sa nadređenim u cilju povećanja poslovnih performansi preduzeća. Cilj istraživanja je da se utvrdi stanje posmatranih organizacionih performansi, zadovoljstva poslom zaposlenih i odnos sa nadređenim u posmatranom preduzeću. Rezultati će biti iskazani kroz praktične predloge o tome kakav odnos nadređeni treba da razvijaju sa svojim zaposlenima, a u cilju postizanja boljih performansi preduzeća. Istraživanje se vrši putem popunjavanja upitnika od strane ispitanika, odnosno, zaposlenih u preduzeću. Sakupljeni su odgovori od ukupno N=33 zaposlena u preduzeću. Rezultati koji su analizirani na dimenziju zadovoljstvo poslom i dimenziju odnos sa nadređenim pokazuju da su zaposleni u posmatranom preduzeću prosečno zadovoljni.

Ključne reči: Zadovoljstvo poslom; Liderstvo; Zaposleni; Organizacija. 